\title{
Biophilic Approach to Design for Children
}

\author{
Nihan Ünal1 ${ }^{\odot}$, Esin Sarıman Özen 2 ๑ \\ ${ }^{1}$ Graduate School of Science, Mimar Sinan Fine Arts University, Istanbul, Turkey. (Principal contact for editorial \\ correspondence), Email: ndaloglu@yahoo.com.tr \\ ${ }^{2}$ Asst. Prof. Dr., Faculty of Architecture, Mimar Sinan Fine Arts University, Istanbul, Turkey. Email: esinsariman@gmail.com
}

\begin{abstract}
Purpose

In recent years, design approaches that offer sustainable solutions have been preferred widely. Although these sustainable design approaches provide solutions for physical context, they are not able to solve the problems on psychological side of this situation. These psychological problems have been observed both on adults and children. This research aims to examine the benefits of enabling children who spend their time in built environments to experience nature through Biophilic Design. Methodology

140 children between the ages of 3 and 5 from two different pre-school institutions participated in the study. Participation criteria were to be volunteer, a pre-school student, and accessible. The pictures drawn by the children in reply to the question 'What is nature like?' were analysed by using content analysis and cognitive mapping method. The data obtained from the study were analysed and the results were presented as median, mean values \pm standard deviations (SD), numbers, and percentages. The compliance of the total score to normal distribution according to age and gender independent variables was examined by the Kolmogorov-Smirnov test. Non-parametric tests were used in the analysis, $p<0.050$ was considered statistically significant. In addition, semi-structured interviews were conducted with the teachers of the participants.
\end{abstract}

\section{Findings}

According to the age groups, the scores of the older age group were found to be significantly higher than the younger age group $(\mathrm{p}=0.000)$. When the relationship between total score and gender was examined, no statistically significant difference was found $(\mathrm{p}=0.074)$.

\section{Research Limitations/Implications}

In the study, even though the necessary permissions were obtained to carry out planned studies with preschool students, due to the prejudices of teachers and administrators, the work that was wanted to be carried out with children was made difficult in some cases.

\section{Originality}

Study originality; in the context of Biophilic Design, is owed to the age range of the chosen focus group, and with the help of this study, the emphasis on what biophilic design can add to the lives of children.

Keywords: Biophilic design, design for children, nature 


\section{INTRODUCTION}

Since the beginning of humanity, nature, which has been a shelter, an educator, and a guide for human being, has become increasingly inaccessible to people due to the requirements of new modern life and concrete jungles that are increasing day by day. However, the need for being in touch with nature subconsciously remains alive. This is not the case for adults only. After the industrial revolution, mass production has become widespread. Since more and more families start sending their children to kindergartens because both parents have been working, this development affects children significantly. As it is difficult to control children's activities when they are outside, they are restricted to stay indoor spaces when they are away from their parents. The literature review process of this investigation has shown that it is important for children to be in touch with nature. Being away from nature negatively affects the future of children and, according to research, causes problems such as learning difficulties, distraction, and anxiety in children. To claim that the connection between children and nature is getting weaker day by day, a fieldwork was conducted to evaluate children's perception on nature. As the result of the study, the perception of children on nature was found weak because of spending more time in indoor places and built environment. As the solution to the situation, biophilic design was suggested. This is why biophilic design approach was thoroughly examined in the context of children spaces selected as the focus group.

\section{LITERATURE REVIEW}

The concept of biophilia was first introduced in 1964 by German-born American philosopher and psychoanalyst Erich Fromm. In his book "The Heart of Man", he summarized the concept of biophilia as the instinct to love and empathize with living things and everything related to life (Fromm, 1964). The concept was revisited in 1984 by the American biologist Edward Osborne Wilson in his book "Biophilia". Wilson, on the other hand, defined the concept of Biophilia as the drive to attach to other lifestyles (Wilson, 1984). This empathy and attachment drive towards life dates back to the beginning of human history and there is an instinctive connection between people and other life forms (Downton et al., 2017). The biophilia hypothesis was offered as a design approach in 2005 by Stephen Kellert in the book titled "Building for Life". The main purpose of this design approach is to reflect the natural environment to the built environment through the design criteria. In the literature review conducted before the study, it was seen that the studies mostly focused on the psychological, physiological, and economic effects of biophilic design on humans. One of the biggest reasons why the author deals with the subject of biophilic design in the context of children in this article, which has been extracted from the thesis, is that he reached the conclusion that there are not enough studies currently done, and another is his belief that the chosen subject will make a great contribution to children. 


\section{Biophilic Design}

Today, thanks to the development of technology and modern building systems, it is an indisputable reality that life is getting easier day by day. Unfortunately, these developments have caused people to consider themselves to be superior to nature, and the inheritance and experiences we receive from nature have begun to lose value (Roös, 2016). The effect of the losing value returns to people as unsustainable energy, depletion of resources, air and water pollution, climate change, waste generation, unhealthy indoor and outdoor environments. (Kellert et al., 2008). Biophilic design, originally meaning the love of nature, has been put forward as a solution to transform this negativity into a positivity and to strengthen the relationship between people and nature.

The purpose of biophilic design is to offer people better experiences in all areas of life psychologically and productively by answering these three questions: how will buildings affect the natural environment? How will nature affect people's experiences and passions? and how can continuous and mutual benefit between these two phenomena be achieved? (Kellert et al., 2008)

As with any design approach, biophilic design has its own criteria as well. These are environmental features, natural shapes and forms, natural patterns and processes, light and space, place-based relationships and evolved human-nature relationships. Each criterion has its own elements, and the aim of each element is to provide the intended human-nature relationship to the users of the built environments. Equipped with the known characteristics of the natural world, this list consists of several aspects such as imitation of the natural world, the integration of properties found in nature into the built environment, the quality of the relationship between light and space, the combination of culture and ecology (Kellert et al., 2008). Including these aspects in the built environment has the potential to enrich nature and humanity (Kellert et al., 2008).

Since the dawn of humanity, nature has played an important educational role. Thanks to the facts and other living things it hosts; people have learned to survive and have been able to improve what they get from nature with the help of their observation skills. Observed creatures and phenomena are summarized with nine elements under the heading of environmental features. These are; colour, water, air, sunshine, plants and animals, fire, view, natural materials and ecosystem. The use of environmental features is the incorporation of elements that already exist in nature with the designed environment. These elements also support the continuation of people's existence. For example; water is one of these elements. Throughout our history, civilizations have always been shaped according to water resources. Water, which constitutes $70 \%$ of our body, is the most important substance after oxygen for our survival. As it is known, the sound and image of water support visual aesthetics by giving people peace and tranquillity (Hildebrand, 2000). The built 
environment containing water images is preferred to the natural environment that does not contain water images (White et al., 2010).

Natural shapes and forms, the second criteria of the biophilic design, consist of eleven elements. These are organic forms, botanical motifs, biomimicry, shells and spirals, shapes resisting straight lines and right angles, biomorphology, geomorphology, egg, oval and tubular forms, simulation of natural features (Sayuti et al., 2015). These elements include the presentation and simulation of the natural environment on building facades and interior spaces (Kellert et al., 2008).

Natural patterns and processes that play an important role in the evolution and development of human being is the third criterion of the Biophilic Design Criteria. For biophilic design, reflecting the reactions and experiences that are acquired from the nature in the built environment design process is as important as reflecting the environmental features and natural shapes and forms. The elements of natural patterns and processes are sensory variability, information richness, growth, change, aging, dynamic balance and tension, ratio and scales, bounded spaces, central focal point, fractals, integration of parts to wholes, and linked series and chains (Sayuti et al.,2015).

The subject of light and space, which is the fourth criterion of the Biophilic Design, consists of the elements of natural light, filtered and diffused light, light and shadow, reflected light, light pools, light as shape and form, warm light, spatial variability and harmony, and inside-outside spaces (Sayuti et al.,2015). People see and perceive their environment thanks to the visual perception of brightness. In order for visual perception to be flawless in any space, the quantity and quality of lighting must be created in accordance with the characteristics of the environment in question (Demircioğlu \& Yılmaz, 2005). Therefore, one of the most important factors in the perception of space is the phenomenon of light.

The fifth biophilic design criterion is place-based relationship. This element implies the successful evolution of culture with ecology in the geographical context. The attachment of humans to places creates a need for territorial control aiming to maintain control and security over resources throughout the evolution of species. Local familiarity and homesickness are the needs that most people feel deeply (Kellert et al., 2008). Place-based relations have eleven elements. These are geographical connection, historical connection, ecological connection, cultural connection, indigenous material, landscape orientation, landscape features that define the built structure, landscape ecology, avoidance of placelessness, the spirit of the place, the integration of culture and ecology (Sayuti et al.,2015).

The sixth and final criterion of biophilic design is the evolutionary human-nature relationship. The criteria mentioned before are based on the physiological connection of humans with nature. 
Table 1. Biophilic Design Criteria (Sayuti et al., 2015)

\begin{tabular}{|c|c|c|}
\hline Environmental Features & $\begin{array}{l}\text { - Colour } \\
\text { - Water } \\
\text { - Air } \\
\text { - Sunshine } \\
\text { - Natural Materials }\end{array}$ & $\begin{array}{l}\text { - Plants and } \\
\text { Animals } \\
\text { - Fire } \\
\text { - View } \\
\text { - Ecosystem }\end{array}$ \\
\hline Natural Shapes and Forms & $\begin{array}{l}\text { - Organic Forms } \\
\text { - Botanical Motifs } \\
\text { - Biomimicry } \\
\text {-Shells and Spirals } \\
\text {-Shapes Resisting Straight } \\
\text { Lines and Right Angles } \\
\text { - Biomorphology }\end{array}$ & $\begin{array}{l}\text { - Geomorphology } \\
\text {-Egg, Oval and } \\
\text { Tubular Forms } \\
\text { - Simulation of } \\
\text { Natural Features }\end{array}$ \\
\hline $\begin{array}{l}\text { Natural Patterns and } \\
\text { Processes }\end{array}$ & $\begin{array}{l}\text { - Sensory Variability } \\
\text { - Information Richness } \\
\text { - Age, Change and The } \\
\text { Patina of Time } \\
\text { - Dynamic Balance and } \\
\text { Tension } \\
\text { - Integration of Parts to } \\
\text { Wholes } \\
\text { - Bounded Spaces }\end{array}$ & $\begin{array}{l}\text { - Transition } \\
\text { Spaces } \\
\text { - Hierarchically } \\
\text { Organized Ratios } \\
\text { and Scales } \\
\text { - Lurks Series } \\
\text { and Chains } \\
\text { - Fractals }\end{array}$ \\
\hline Light and Space & $\begin{array}{l}\text { - Naturel Light } \\
\text { - Filtered and Diffused } \\
\text { Light } \\
\text { - Light and Shadow } \\
\text { - Reflecting Light } \\
\text { - Warm Light }\end{array}$ & $\begin{array}{l}\text { - Light Pools } \\
\text { - Light as A } \\
\text { Shape and Form } \\
\text { - Spatial } \\
\text { Variability } \\
\text { - Inside - Outside } \\
\text { Spaces }\end{array}$ \\
\hline Place-Based Relationship & $\begin{array}{l}\text { - Geographic Connection } \\
\text { - Historical Connection } \\
\text { - Ecological Connection } \\
\text { - Cultural Connection } \\
\text { - Landscape Orientation } \\
\text { - Landscape Features } \\
\text { Defining Building Form } \\
\text { - Indigenous Materials }\end{array}$ & $\begin{array}{l}\text { - Avoiding } \\
\text { Placelessness } \\
\text { - Spirit of Place } \\
\text { - Integration of } \\
\text { Culture and } \\
\text { Ecology } \\
\text { - Landscape } \\
\text { Ecology }\end{array}$ \\
\hline $\begin{array}{l}\text { Evolved Human- Nature } \\
\text { Relationships }\end{array}$ & $\begin{array}{l}\text { - Prospect and Refugee } \\
\text { - Order and Complexity } \\
\text { - Change and } \\
\text { Metamorphism } \\
\text { - Security and Protection } \\
\text { - Exploration and } \\
\text { Discovery } \\
\text { - Fear and awe }\end{array}$ & $\begin{array}{l}\text { - Curiosity and } \\
\text { Enticement } \\
\text { - Information } \\
\text { and Cognition } \\
\text { - Attraction and } \\
\text { Beauty } \\
\text { - Affection and } \\
\text { Attachment }\end{array}$ \\
\hline
\end{tabular}

The evolutionary human-nature relationship is about how people have nature in their inner world and what nature means to them. In other words, evolutionary human-nature relationship focuses on fundamental aspects of the internal human relationship with nature (Kellert, 1997). The elements of the evolutionary nature-human relationship criteria are 
prospect and refugee, order and complexity, change and metamorphosis, security and protection, exploration and discovery, fear and awe, curiosity and enticement, information and cognition, beauty and attraction (Sayuti et al.,2015).

\section{Implication areas of biophilic design}

It is possible to experience and apply biophilic design to many different scales. By considering biophilic design strategies at very early stages of the design processes, opportunities regarding building layout, architectural form, interior layout, interior design and landscape can be more easily obtained. Enabling users to correlate spaces visually, ecologically, historically and culturally, with the help of biophilic design criteria at different scales, will help them to adopt and protect the built environments. These scales can be summarized under four headings as urban design, architecture, interior architecture and industrial design. Under the title of biophilic design application areas, the relationship of biophilic design with these four different scales will be exemplified.

One of the examples that can be given in the context of the use of biophilic design in urban scale, which is the first subtitle of biophilic design application areas, is to provide open spaces by leaving gaps between buildings. In this way, it is possible to prevent people from being exposed only to structures, and to ensure that they have areas where they can interact with nature more closely. In addition, when these pre-planned open areas are left during construction with respect to the natural environment, the protection and utilization of local trees and vegetation will be ensured. In addition to providing low costs, this may ensure that the damage to the natural life from the constructional work can be minimized.

Another biophilic decision that can be made on an urban scale is to create pathways for walking and cycling in these spaces in order to define and make sense of the spaces to be left around the buildings.

Applying green walls to the facades of buildings and green roofs to the top of the buildings will not only ensure that nature is preferred over artificial materials as an insulation material, and also, they can be proofs that more environmentalist approach is preferred since rain and snow water can reach the soil filtered by the green walls and roofs (Çorakçl, 2016).

When it comes to the biophilic design applications at architectural scale, some of the most common applications can be listed as: shaping the facades focusing on the natural view, making maximum use of daylight, using movable spaces on the facades, preferring green roof applications, preferring organic shapes and forms, including water as a design element in the building, and referring to the feeling of spaciousness and security in the design. Such design decisions on an architectural scale can increase the sense of nature on users, increase the efficiency of the buildings and put depth and diversity on the designed spaces. 
Choosing Biophilic Design as a design strategy in interior architecture scale brings out some advantages such as increasing work efficiency of the users, accelerating their healing processes, making them feel closer to the nature and keeping them away from the stress factors. Using pot plants, indoor gardens, natural building materials, pictures with natural views as part of the design, and designing living or working places in such ways that they can look outside the windows or interior gardens and they can make the most of natural light are some of the examples that will meet biophilic design criteria in interior architecture scale.

The last scale is the industrial design scale. As in other scales, the priority of Biophilic Industrial Design is directly or indirectly to give the users the connection to the nature that they need with the help of the design products they may use in the built environment. Although it is still developing and still not fully mature, industrial design scale continues its progress under different sub-headings. These subheadings are indoor air cleaners, materials and processes are sustainable energy production and interconnected household appliances.

\section{Effects of biophilic design}

Humanity owes their present achievements to the correct evaluation of what nature has given to them. Nature has always been a shelter for people, and a teacher and a way of therapy when appropriate. As biological creatures, humans have not fully adapted to today's sterile technological cities psychologically, physiologically and emotionally (Burns, 2005). This is one of the reasons why stress level on people overcome stress is to increase people's contact with nature, which seems less accessible today. With the help of natural contact, it is possible to reduce the effects of many situations that negatively affect our lives. Biophilic design as a design trend is seen a design approach that can help human being in this sense. As Wilson and Kellert emphasized in their book Biophilia Hypothesis, feeding the innate love and connection with nature in humans can not only help people go beyond the basic needs such as food, but also become fundamental for human well-being in urban life (Kellert \& Wilson, 1993). While examining the effects of biophilic design, it is possible to collect the data found under different classes. These classes are psychology, physiology, environment and economy. According to the biophilia hypothesis, the main reason for the positive effects of exposure to nature is the biological bond between man and nature (Wilson, 1984). Disengagement from nature, which is one of the negative effects of the modern world, unfortunately weakens the humannature relationship. The achievement of this relationship can be demonstrated by the Attention Repair Theory (ART) and Stress Healing Theory (SRT) in the Environmental Psychology literature (Joye, 2012). According to ART; attention deficit can be repaired by exposure to natural environments (Fan \& Jin, 2013). According to Kaplan, just displaying pictures of nature is sufficient for increasing a person's cognitive 
function, mental state and working capacity (Berman et al., 2008). On the other hand, there are some possible negative effects of attention fatigue. Some of them are to make the wrong decisions, to lose the personal control mechanism, even to become obese (Hare et al., 2009).

Another benefit of the biological bond between humans and nature is, according to SRT; contact with the non-threatening natural environment during stress will reduce the stress level compared to the built environment (Zajonc, 1980). The power of nature, advocated by ART and SRT, is one of the examples that positively affect people in the built environment in a psychological context thanks to the biophilic design.

Deficiency of any environmental representation of the nature not only disturbs people in a psychological context, but can also lead to physiologically negative symptoms and reactions (Söderlund \& Newman, 2015). In the past, biophilic design was used consciously or unconsciously to ensure that people are positively affected psychologically and physiologically by imitating the communication with nature in built spaces to contribute to people. For example, as the architectural theorist Christopher Alexander states in his book "A Pattern Language" published in 1977, reflecting and transporting the pattern language of nature to the built environment makes people feel more alive and more human (Alexander, 1977). Nowadays, Biophilic Design applications are discussed by designers in order to exhibit this approach in their designs consciously and to affect the users better in a physiological context.

Biophilic Design can physiologically help humans in many ways such as low blood pressure, reduction in symptoms, accelerated healing and improved physical fitness. According to the findings obtained by medical doctors Park and Mattson as a result of their study with 90 patients who were undergone appendicitis surgery, it has emerged that the plants used in the hospital environment are an affordable and complementary medicine for patients who are in recovery phase after the surgery. It was determined that patients with plants in their rooms demanded fewer painkillers, their blood pressure was more regular and they were more satisfied with their hospital rooms (Park \& Mattson, 2008). The effects of global warming, one of the biggest problems of today, are increasing day by day due to the decrease in green areas, the decrease in biodiversity, water and air pollution, unplanned urbanization, the formation of urban heat islands and the increase in energy consumption. It is possible to minimize these negative effects with the correct application of biophilic design at different scales. The decrease in green areas, which is one of the results of unplanned urbanization, causes other negative consequences. There are many benefits of using green facades and roofs as green areas has many benefits as well as being a solution to these problems. One of these benefits, thanks to the controlled use of vegetation, it is possible to manage waterway pollution with the help of vegetation's water absorption and absorption ability. In addition, the cleaning of the soil, whose water holding capacity is increased due to the fact that the water 
that the soil cannot absorb during rainfall is brought to the soil by planting, is another of these benefits. Control of rainwater flow as a result of vegetation used on the roof and facade will also reduce floods (Ostendorf et al., 2011). The efficiency of rainwater utilization varies according to the climate, seasons, plant types that are used, roof slope and substrate depth. Providing the appropriate combination of all these elements can increase this efficiency by 70\% (Schroll et al., 2011). Vertical green walls and green roofs also have a minimum footprint and contribute significantly to the aesthetics of the urban environment. They have the potential to meet the water required for their maintenance through the recirculation of the wastewater they recycle due to the reduction of rainwater flow (Burrows \& Corragio, 2011).

There are also economic effects of biophilic design. These are increase in employee productivity, accelerated recovery in patients, and increase in product sales in stores. Today efficiency costs are 112 times higher than energy costs in the workplace. Thanks to the investments in efficiency, it is possible to save 2000 \$ per employee a year. This situation is similar not only to workplaces, but also to hospitals whose patients recover faster, to factories with increased efficiency, to schools that improve exam results, and to stores that increase sales (Browning et al., 2012). Another example of economic impacts of biophilic design, by the integration of biophilic approach in urban scale, is possible to conserve resources, optimise energy water and waste systems, which in return will affect the users in a positive way economically (Thomson \& Newman, 2021).

\section{The importance of biophilic design for children}

The reason for biophilic design to become more and more important is the side effects of modern life daily routines. Because of these increasing daily routines after school activities for children, the time spent indoors have become longer, and technological devices have been used more and more. Also, the anxiety level of parents for their children's security has raised. These are the reasons that weaken the bond between nature and children because children are spending less time in nature. This situation as a conclusion, starts a chain reaction which leads people to become estranged to nature. Increase in obesity, vitamin D deficiency, hyperactivity and attention deficit disorder occurs in children as other results (Faber et al., 2006). Another effect of being diverged from nature on children is the way they become afraid of and uninterested in nature (Berg \& Medrich, 1980). To avoid this, using natural elements in built environment can be a solution (Day, 2007).

Biophilic design gives people the opportunity to communicate with nature and understand the local cycles of nature at the urban scale as well. Bringing these cycles to children's perceptions contributes to their social and physical development (Ginsburg, 2007). On the other hand, it has been observed that families who spend time in nature prefer these areas for their children and themselves, and they feel safer when they are 
in these areas (Kuo \& Sullivan, 2001). As biophilic design provides benefits for adults, it also provides several benefits for children as well. These are improvement in their self-esteem level, development of motor skills, increase in cognitive functioning and attention capacity (Wells et al., 2003).

It is possible to make the space more convertible by using biophilic design elements. If the children have the opportunity to convert and transform the materials that are used in a space by them, this would make the children gain independence (Derr \& Lance, 2012). Allowing children transform the built environment they use can bond them with the idea of nature. Because nature is the place where they can be completely free to play with anything they want as much as they want. It is possible in nature for rocks to become thrones and for bushes to become rockets (Derr, 2001).

\section{METHOD}

Since the focus group of the study is students between the age of three and five, and since the interviewees are not capable of understanding the notion of biophilia, the people to be interviewed for the semi-structured interview were selected from their teachers. The reason for choosing semi-structured interview method is to be able to explain the questions during the interview process and to inform the interviewee where necessary (Berg \& Howard, 2015). Another reason for the semistructured interview is that the order of pre-prepared questions can be changed during the interview according to the flow of the interview, and the possibility of better communication with the respondents thanks to the flexibility of the interview language. Questions can be left more openended than the standardized interview type, and therefore the interviewees are expected to provide more detailed information (Derr, 2001).

The teachers selected for the interview were selected from Safranbolu district of Karabük Province in the context of convenience sampling, thanks to the author's ease of access to people and information (Yamane, 2009). Pre-school education units in Safranbolu are divided into two groups as state-owned institutions and independent private institutions. Branch selection has been determined as state institutions and the reason for this is that there are more students in these institutions due to socioeconomic reasons. The schools of the teachers interviewed were chosen by simple random sampling from random sampling methods. The reason for this was to equalize the probability of participations of teachers and workplaces. For this reason, the names of all schools affiliated to the state were written on individual papers and put in bags, and drawn from the bag. Thanks to randomness, all schools are given equal probability (İslamoğlu \& Alnıaçık, 2014). The teachers interviewed in the selected schools were determined on a voluntary basis. As a criterion, teaching in pre-school institutions was taken. The questions asked to teachers during the interviews were in Turkish because their mother tongue was Turkish 
and they can express themselves more easily. The translated questions are as follows;

1. Do you include extracurricular activities in your annual curriculum? If you include out-of-class activities, what are these activities?

2. How many hours do you get round to these activities per week?

3. What are the qualified natural environment activities of your students?

4. What are the attitudes of your students towards qualified natural environment activities comparing to their attitudes towards classroom activities?

5. How are your students' participations in qualified natural environment activities compared to their participations in class activities?

6. Is it possible to facilitate your students' first-time experience of being away from their homes and families with biophilic design?

7. What are the benefits of taking lessons in qualified natural environments?

Another method used in the study is literature review. In order for the examined documents to be objective, the researches on the topics discussed have been provided from many sources. The aim here is to continue the investigation and present the correct information, even if there are conflicts in the literature about the subject (İslamoğlu \& Alnıaçık, 2014). During the literature review process, Biophilic Design, the relationship between nature and children, and design for children were investigated in detail and comparatively.

Another method is the cognitive mapping method. The reason for using this method is that the age of the children in the focus group is not suitable for verbal interviews. For this purpose, children were asked to paint with a material of their selection, as an answer to the given question. Some randomly selected pictures made by the children are given below in Table 2 .

Figure 1. Sample pictures drawn by the children

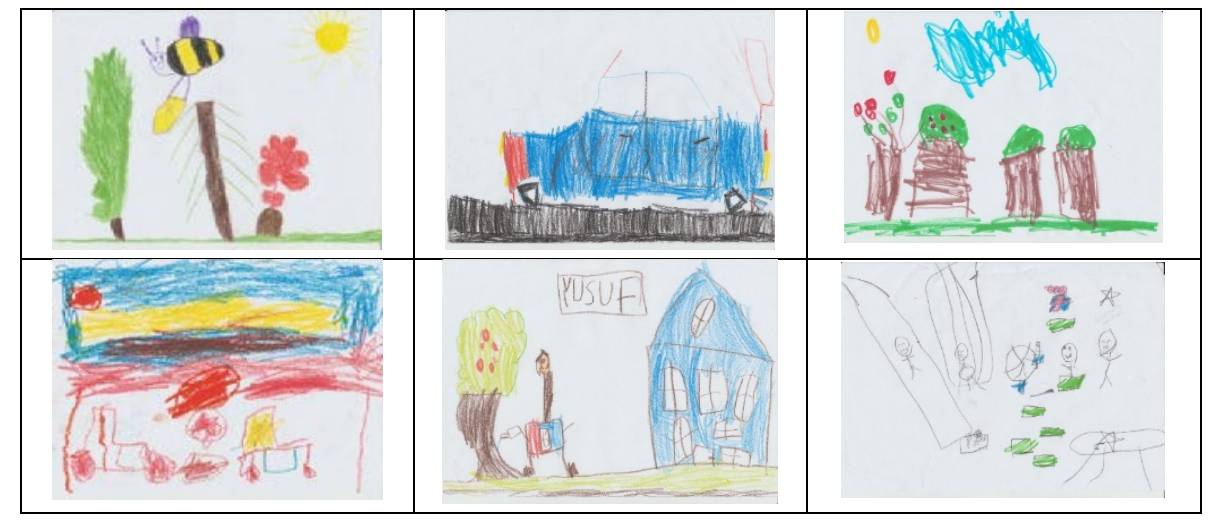

The pictures made by the participants were detailed by using the content analysis method and the used elements were categorized. The elements and sub-categories of animate and inanimate elements were listed in Table 3. In Table 4, the number of usages of animate and inanimate elements were shown, and in Table 5, the number of colour usage were given. Then, with the content analysis method, what the elements used in 
the pictures mean for children in a cognitive context was determined. 140 (54 boys, 86 girls) preschool children from two state schools in Safranbolu district of Karabük province attended the research. The pictures made by the participants were scored according to the subtitles of plants, animals, humans, natural elements and human elements under two main headings (animate elements, inanimate elements) in the answer key created by using the content analysis. Plants, animals, human and natural elements were evaluated as +1 , while human factors were evaluated as -1 . This means that a picture can get +1 point for every animate element, and -1 , if there is an inanimate element in the picture drawn. To make the long story short, the range of points a picture can get varies between -1 and 4 points.

Scoring was done by 3 experts who did not know each other, one of which was a child psychiatrist, a psychiatrist, and a psychologist. The experts evaluated the pictures in a way which was stick to the table created as a result of the content analysis made over the pictures. Evaluation scores varied between -3 and 12 points when all 3 scores given for a picture by the experts were added up. To evaluate the consistency between the experts, the correlation was also analysed by using SPSS. While analysing the correlation between the scores that were given by the experts, correlation coefficients test was used. The correlation of the results that were taken from the experts was also analysed by binary combination and every pair was compared to each other.

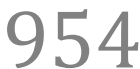

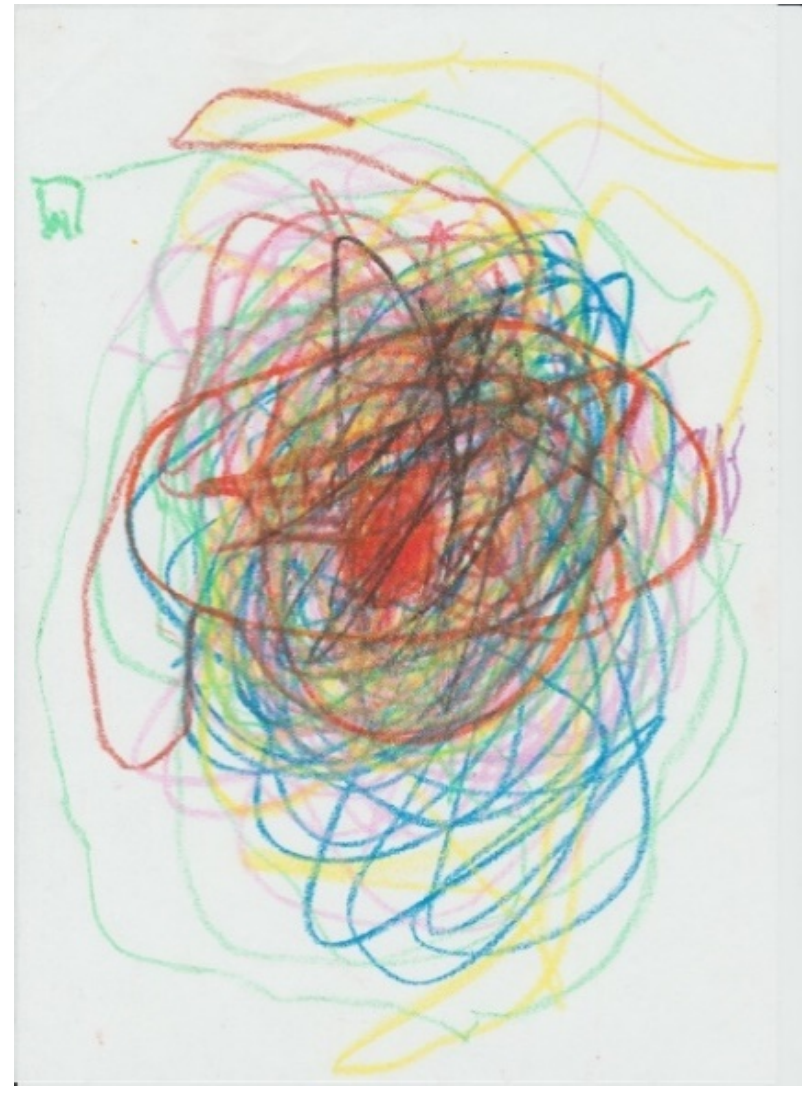

Figure 2. Unidentified Picture.

Pictures are categorized as unidentified by the 3 experts in the evaluation stage. 
Table 2. Evaluation of the pictures by the experts according to the group distributions

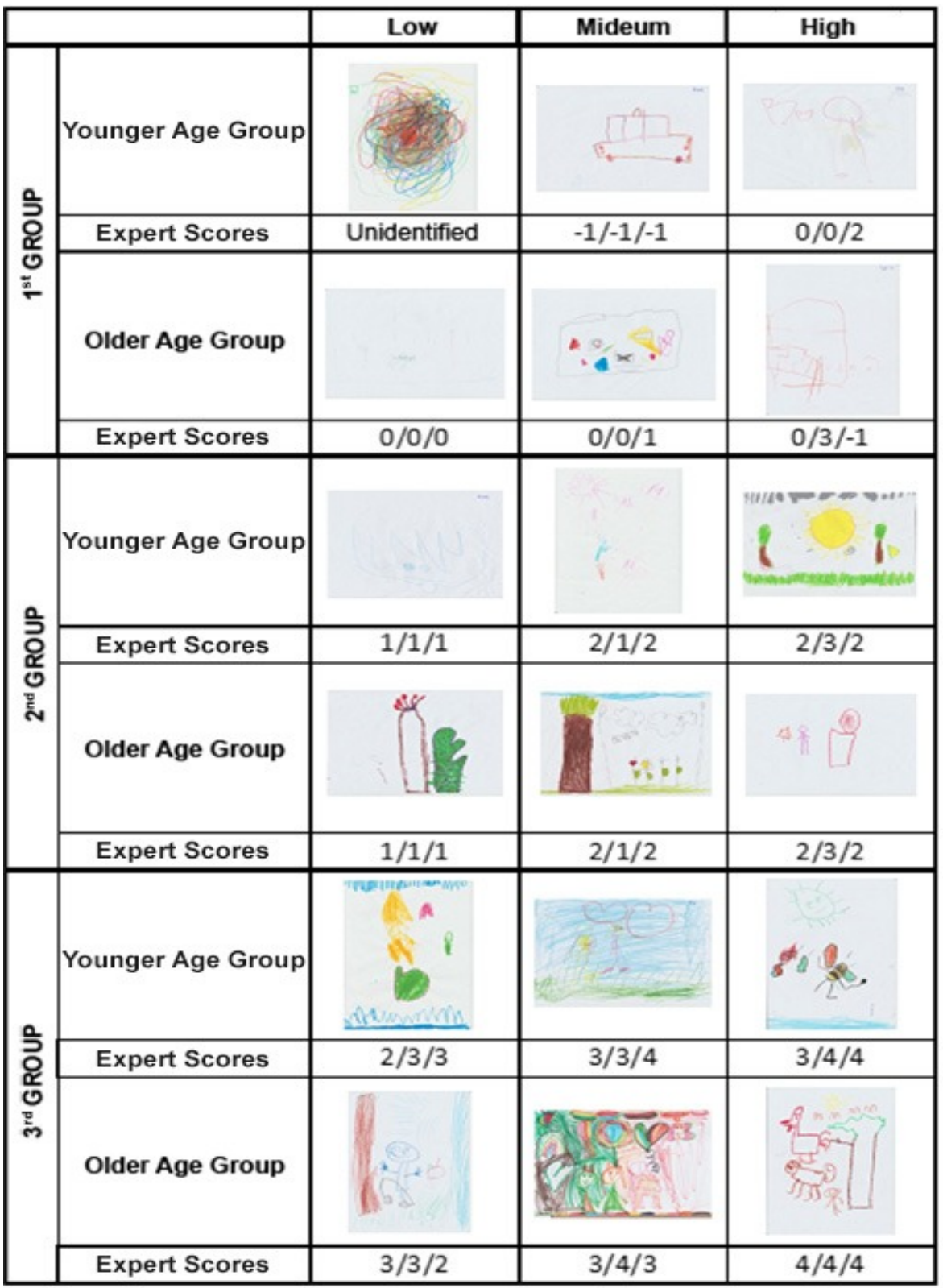

In the Table 3 above, sample evaluations of the experts can be seen. The schools that the intervention was done are shown as $1^{\text {st }}$ Group, $2^{\text {nd }}$ Group and $3^{\text {rd }}$ group. The age categories of students in their schools were determined as follows: Students at the age of 3 and 4 were taught in one group and students at the age of 4 and 5 were taught in another group. Younger students are shown as the younger age group, and older students are shown as the older age group in the table. From every group in every school, sample pictures getting high, medium or low scores, and evaluation scores of all 3 experts for these sample pictures were given. 

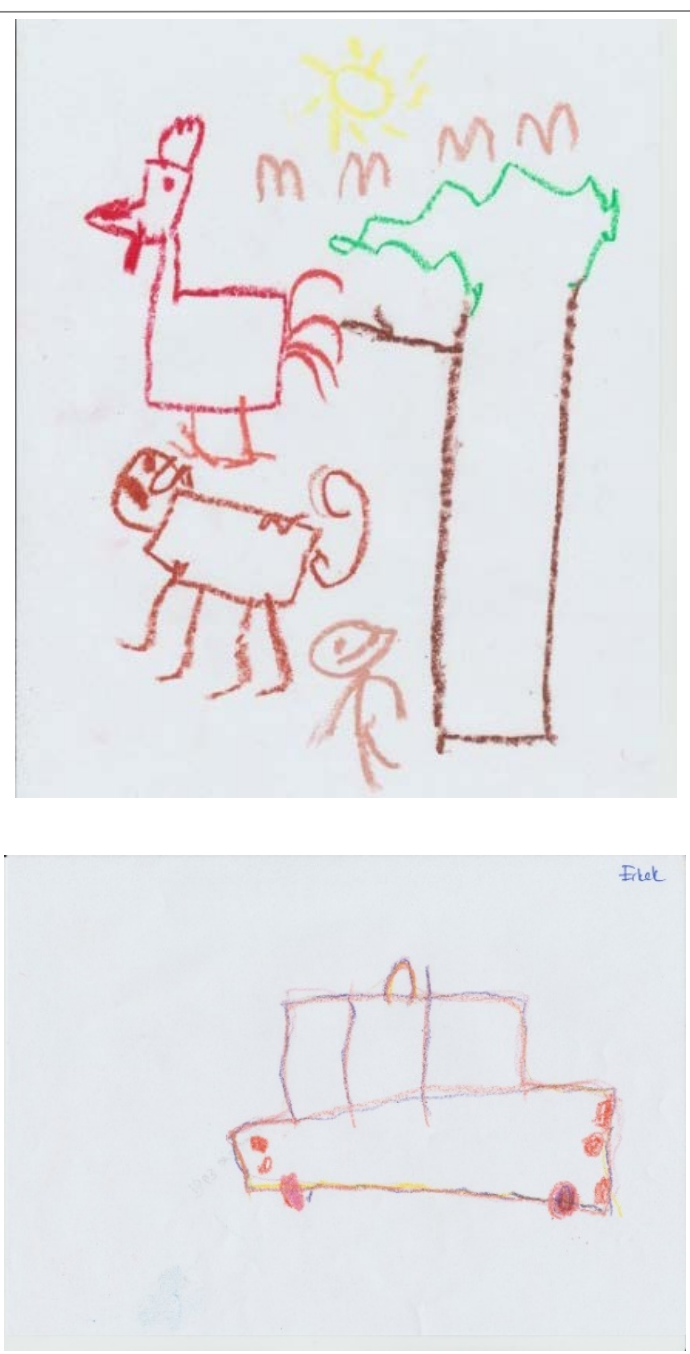

The data obtained from the study were analysed using SPSS, Version 22.0 (SPSS Inc., Chicago, Illinois, USA) and the results are presented as median, mean values \pm standard deviations (SD), number and percentage. To see if age and gender variables follow the normal distribution, the Kolmogorov-Smirnov test, which is a commonly-used test to understand if the collected data is statistically significant or not, was conducted. Nonparametric tests were used in the analysis because the data did not fit into the normal distribution. The value $\mathrm{p}<0.050$ was considered statistically significant. In the Table 4 below, it can be seen that the $p$ value $(p=.001)$ is lower than .050 . It can be interpreted that the data collected are statistically significant and follow the normal distribution.

Table 3. Tests of Normality

\begin{tabular}{|l|r|r|r|}
\hline \multicolumn{4}{|c|}{ Tests of Normality } \\
\hline \multirow{2}{*}{} & \multicolumn{3}{|c|}{ Kolmogorov-Smirnov ${ }^{\mathrm{a}}$} \\
\cline { 2 - 4 } & Statistic & $\mathrm{df}$ & \multicolumn{1}{c|}{ Sig. } \\
\hline $\begin{array}{l}\text { total } \\
\text { scores }\end{array}$ &, 103 & 136 &, 001 \\
\hline
\end{tabular}

Figure 3. A 12-Point Picture. The highest score that a picture can get as the results of the evaluations done by the experts is 12 .

Figure 4. A 3-Point Picture. The lowest score that a picture can get as the results of the evaluations done by the experts is -3 . 
Table 4. Content Analysis Table

\begin{tabular}{|c|c|c|}
\hline \multicolumn{3}{|c|}{$\begin{array}{l}\text { The elements that children use to answer the question; What is nature like? } \\
\text { (141 Children) }\end{array}$} \\
\hline Theme & Category & Expressions \\
\hline \multirow{3}{*}{$\begin{array}{l}\text { Animate } \\
\text { Elements }\end{array}$} & Plants(110) & $\begin{array}{l}\text { Tree (49), Grass (24), Flower (16), Apple } \\
\text { (13), Greenery (7), Cactus (1) }\end{array}$ \\
\hline & Animals(26) & $\begin{array}{l}\text { Butterfly(4), Bee(3), Bug (3), Dog (3), Bird } \\
\text { (2), Chicken (2), Octopus (1), Whale (1), } \\
\text { Brood (1), Turtle (1), Lizard (1), Olaf } \\
\text { (1),Chipmunk (1), Fox (1), Dolphin (1) }\end{array}$ \\
\hline & $\begin{array}{l}\text { Human Beings } \\
\text { (57) }\end{array}$ & $\begin{array}{l}\text { Kid(32), Family(11), Girl(8), Man (3), Mother } \\
\text { (1), Me (1), Doctor (1) }\end{array}$ \\
\hline \multirow[b]{2}{*}{$\begin{array}{l}\text { Inanimate } \\
\text { Elements }\end{array}$} & $\begin{array}{l}\text { Natural } \\
\text { Elements(158) }\end{array}$ & $\begin{array}{l}\text { Sun (51), Cloud (41), Mountain (13), Rainbow } \\
\text { (13), Sky (13), See (12), Rain (4), Lake (3), } \\
\text { Honey (2), Earth (2), Moon (1), Land (1), Rock } \\
\text { (1), Water Pond (1) }\end{array}$ \\
\hline & $\begin{array}{c}\text { Artificial } \\
\text { Elements(102) }\end{array}$ & $\begin{array}{l}\text { House (21), Car (16), Hearth Symbol (13), } \\
\text { Ball (6), Bag (4), Pot (3), Kite (3), Road (3), } \\
\text { Balloon (2), Submarine (2), Ship (2), } \\
\text { Hammock (2), Motorcycle (2), Rail Way (2), } \\
\text { Bike (1), Tent (1), Ice Cream (1), Mouse Trap } \\
\text { (1), Garage (1), Air Pollution (1), Light (1), } \\
\text { Square (1), Slide (1), Ashtray (1), Toy (1), } \\
\text { Rocket (1), Swing (1), Water Cup (1), } \\
\text { Ornament(1), Hat (1), Humming Top (1), } \\
\text { Traffic Light(1), Trampoline(1), Triangle (1), } \\
\text { Bed (1), Christmas Tree(1) }\end{array}$ \\
\hline Colours & \multicolumn{2}{|c|}{ 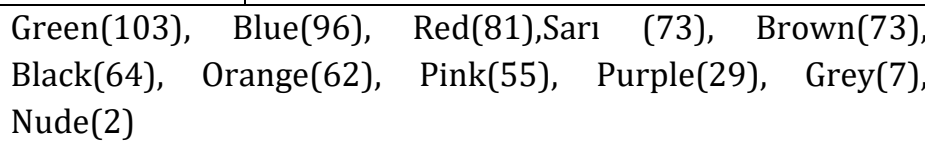 } \\
\hline
\end{tabular}

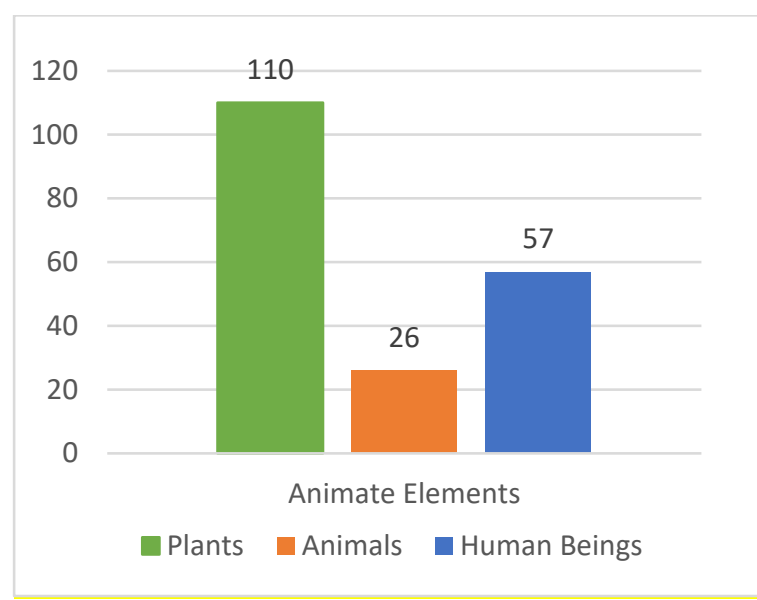




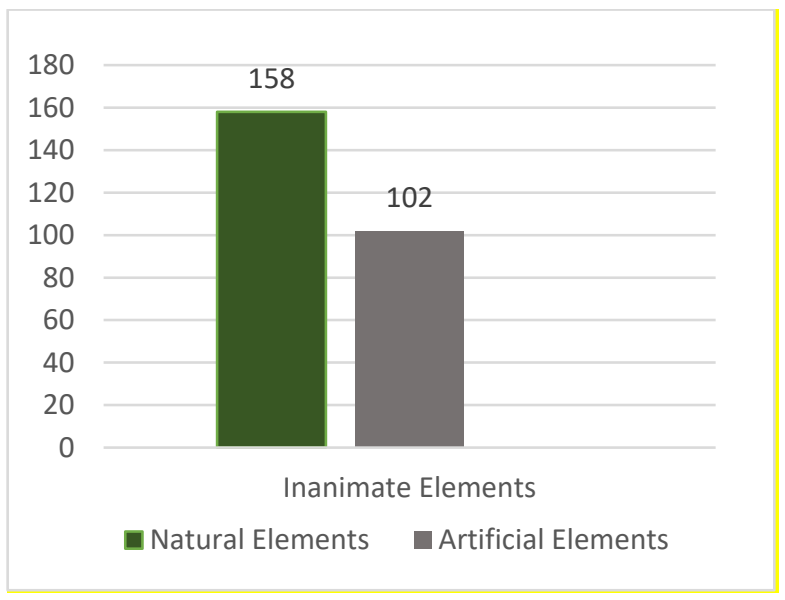

Figure 6. Inanimate Elements

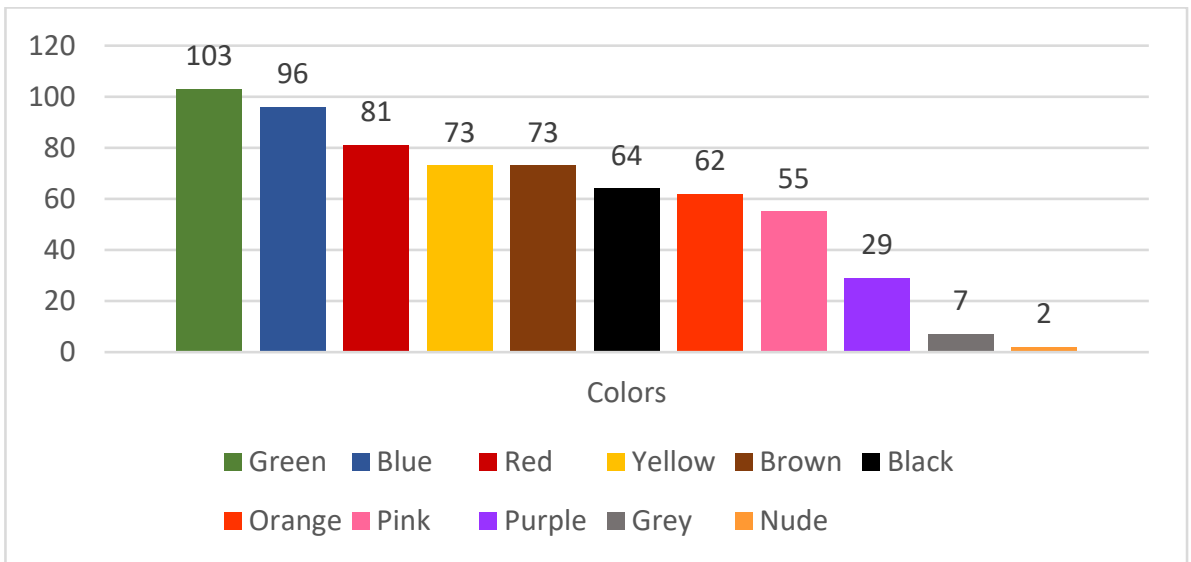

Figure 7. Usage of colours

\section{RESULTS}

As a result of the cognitive mapping method, the pictures made by 140 children in response to the question of "what is nature like?" were analysed by 3 independent experts using the table created with the content analysis method as the evaluation rubric. 11 pictures that could not be defined and categorized as unidentified by the experts according to the rubric were excluded from the study. Sample unidentified picture is shown in Figure 1. A total of 129 children, of which 50 (38.8\%) were boys and $79(61.2 \%)$ were girls, were accepted. There were 32 students (24.8\%) in the younger age group (3-4 years) and 97 students $(75.2 \%)$ in the older age group. They can be seen on the Table 9 below.

Table 5. Distribution of the focus group by age and gender

\begin{tabular}{|l|l|l|l|l|}
\hline \multicolumn{2}{|c|}{} & Younger age group & Older age group & Total \\
\hline Gender & Boy & 8 & 42 & 50 \\
\cline { 2 - 5 } & Girl & 24 & 55 & 79 \\
\hline Total & 32 & 97 & 129 \\
\hline
\end{tabular}


The total mean score obtained from the pictures made by the participants was 5,59 \pm 3.1158 (min: -3 , max: 12), standard deviation (SD) was 4,58, with a median of 6 .

The correlation between the scores of the 3 experts who made the evaluations was examined. The internal consistency of the evaluations of all three experts was found to be above 70\%. (E1 / E2: 71.5\%, E1 / E3: 77.3\%, E2 / E3: 72.3\%) Being above 70\%, in terms of internal consistency means that the correlations among the experts can be accepted as significant. Table 10 shows the detailed correlations among experts.

Table 6. Correlation analysis between experts

\begin{tabular}{|c|c|c|c|c|c|}
\hline & & & Expert 1 & Expert 2 & Expert 3 \\
\hline $\begin{array}{l}\text { Spearman's } \\
\text { rho }\end{array}$ & $\begin{array}{c}\text { Expert } \\
1\end{array}$ & $\begin{array}{l}\text { Correlation } \\
\text { Coefficient }\end{array}$ & 1,000 &, $715^{* *}$ &, $773^{* *}$ \\
\hline & & Sig. (2-tailed) & & 000 & 000 \\
\hline & & $\mathrm{N}$ & 129 & 129 & 129 \\
\hline & $\begin{array}{c}\text { Expert } \\
2\end{array}$ & $\begin{array}{l}\text { Correlation } \\
\text { Coefficient }\end{array}$ & ,715* & 1,000 & ,723** \\
\hline & & Sig. (2-tailed) & 000 & . & 000 \\
\hline & & $\mathrm{N}$ & 129 & 129 & 129 \\
\hline & $\begin{array}{c}\text { Expert } \\
3\end{array}$ & $\begin{array}{l}\text { Correlation } \\
\text { Coefficient }\end{array}$ &, $773^{* *}$ &, $723^{* *}$ & 1,000 \\
\hline & & Sig. (2-tailed) & ,000 & 000 & . \\
\hline & & $\mathrm{N}$ & 129 & 129 & 129 \\
\hline
\end{tabular}

When the total scores of the participants according to their age groups were examined, the scores of the older age group were found to be significantly higher than the younger age group $(p<0.000)$. When the relationship between total score and gender was examined, no statistically significant difference was found ( $p<0.074)$.

On Table 11, score distributions of pictures drawn by the participants were given in detail. The scores that the children took (between -3 and 12 points) were divided into 3 groups: Group 1, from -3 to 2 points, the group 2, from 3 to 7 points, and the group 3 from 8 to 12 points. There are 17 children in the first group, 76 children in the second group and 36 children in the third group. The children in the first group were defined as the ones with the lowest nature perception and experience; the children in the second group as those with medium nature communication; and the children in the third group as those who had a good relationship with nature. 
Table 7: Score distributions of 'What is nature like?' pictures

\begin{tabular}{|c|c|c|c|c|}
\hline & Points & Number & Percentage & \\
\hline \multirow[t]{5}{*}{ Group 1} & -3 & 3 & 2,3 & \multirow{5}{*}{$\begin{array}{c}17 \text { children } \\
\% 13,2\end{array}$} \\
\hline & -1 & 3 & 2,3 & \\
\hline & 0 & 4 & 3,1 & \\
\hline & 1 & 2 & 1,6 & \\
\hline & 2 & 5 & 3,9 & \\
\hline \multirow[t]{5}{*}{ Group 2} & 3 & 13 & 10,1 & \multirow{5}{*}{$\begin{array}{c}76 \text { children } \\
\% 58,9\end{array}$} \\
\hline & 4 & 15 & 11,6 & \\
\hline & 5 & 12 & 9,3 & \\
\hline & 6 & 19 & 14,7 & \\
\hline & 7 & 17 & 13,2 & \\
\hline \multirow[t]{5}{*}{ Group 3} & 8 & 8 & 6,2 & \multirow{5}{*}{$\begin{array}{c}36 \text { children } \\
\% 27,9\end{array}$} \\
\hline & 9 & 19 & 14,7 & \\
\hline & 10 & 5 & 3,9 & \\
\hline & 11 & 3 & 2,3 & \\
\hline & 12 & 1 & 0,8 & \\
\hline TOTAL & & 129 & 100 & \\
\hline
\end{tabular}

The aim of this study is to emphasise the importance and the benefits of biophilic design for children to provide a solution for alienating from nature. The reason to investigate this situation was the negative results of modern daily life such as spending more time in indoors, having fewer green areas in neighbourhoods and in return, being unable to benefit from the nature. Because of having a weaker connection to the nature every day, this study suggests integrating biophilic design into children's spaces can increase the relationship between children and nature.

\section{DISCUSSION}

The starting point of the study was to minimize the negative effects of staying away from nature on adults and especially children with the help of Biophilic Design. Due to the pandemic that has affected the whole world, this issue has become much more important today. People began to realize they need nature more because of the days and even weeks they spent in quarantine due to the Covid-19 pandemic. This period has shown how much we need this design approach beyond the importance of Biophilic Design.

In this period, people have had to focus on different solutions in a spatial context due to the Covid-19 outbreak. The reason for this is the social distance rules that people must provide in order to protect themselves and their relatives. Due to the new regulations in indoor and outdoor places in accordance with social distance rules and the fear of virus, people have started to prefer natural environments over built environments. They started to spend most of their time in isolation due to quarantine (Sever, 2020). As a result, people are now in search of ways 
to bring nature to their homes. For this reason, Biophilic Design provides useful solutions for these difficult times. For further researches, the effects of the pandemic on people's psychology can be discussed to see if Biophilic Design can serve well for this particular situation.

\section{CONCLUSION}

It is known that the absence of connection to the nature in a human being's life has severe affects. These can be sorted as fearing from mother nature, lack of vitamin D, hyperactivity, attention disorder, obesity. Unfortunately, these consequences are not the only ones. These problems also lead to other problems which create a chain reaction that in return, affect a person's life entirely in a negative way.

Day by day, increasing daily modern time requirements keeps people away from the nature. The more daily workloads and workhours mean the less time spent on personal needs. As a result of this, people spend most of their times indoors. It causes their children to be kept closed indoor places too. This is why children are not able to benefit from what nature brings for them.

This article which has been produced from a doctoral thesis, aims to bring a solution to this chain reaction. By using Biophilic Design in a built environment especially for children spaces, a lot of children can be able to taste what it would be like to be in nature. As it was emphasized, absence of connection to the nature may cause health disorders, such as attention-deficit hyperactivity disorder, stress, obesity, and depression. Unfortunately, these are not the only effects that nature disconnection causes. Also alienating from nature causes children to lose their motivation to protect it (Hand et al., 2017). By using biophilic design elements, it is possible to increase the positive effects that nature can bring to children. For example, if the choice of materials is made accordingly with natural materials, this decision can promote the users feel relaxed. By using biophilic design criteria such as prospect and refuge, it is possible to make the users increase the concentration time and ability to perceive safety. Another solution can be about light and space. To increase comfort, happiness, and productivity, dynamic and diffused light applications can be effective (Park \& Lee, 2019).

During the fieldwork, the aim was to understand the perception of the chosen group about the nature. It was to be able to claim that children need Biophilic Design approach in their lives to understand and benefit from nature even in an artificial environment. According to the results of this study, as it was written before, the target group shows that most of the children participants have a weak nature perception. This is why another aim of this work is to emphasize how important it is to make the most of the nature elements and to have a better connection with nature. So, a positive chain reaction can be created. The use of biophilic design approach applications in the built environments, where children spend most of their lives, strengthening the perception of nature for them has a crucial importance. In this way, children will be able to benefit from the 
experiences that nature can provide for them, even if they are in the built environment.

\section{ACKNOWLEDGMENT}

This article is an excerpt from Nihan Ünal's PHD Dissertation originally titled "Çocuklar İçin Tasarımda Biyofilik Yaklaşım” and supervised by Dr. Esin Sarıman Özen at Mimar Sinan Fine Arts University.

\section{FINANCIAL DISCLOSURE}

The authors declared that this study has received no financial support.

\section{CONFLICT OF INTEREST}

No conflict of interest was declared by the authors.

\section{ETHICS COMMITEE APROVAL}

Ethics committee approval was not required for this article.

\section{LEGAL PUBLIC / PRIVATE PERMISSIONS}

In this research, the necessary permissions were obtained from the relevant participants (individuals, institutions and organizations) during the survey, in-depth interview, focus group interview, observation or experiment.

\section{REFERENCES}

Alexander, C. (1977). A Pattern Language: towns, buildings, construction. Oxford University Press.

Berg, B. L. \& Howard, L. (2015). Sosyal Bilimlerde Nitel Araştırma Yöntemleri. (136-139). Eğitim Yayınevi.

Berg, M. \& E. Medrich. (1980). Children in four neighbourhoods: the physical environment and its effect on play and play patterns. Environment and Behavior, 12(3), 320-348.

Berman, B. G., Jonides, J. \& Kaplan, S. (2008). The cognitive benefits of interacting with nature. Psychological Science, 19,1207-1212.

Browning, B., Garvin, C. \& Ryan, C. (2012). The economics of biophiliawhy designing with nature in mind makes financial sense. https://www.terrapinbrightgreen.com/reports/the-economics-ofbiophilia/

Burns, G. W. (2005). The Science of Well-being. Oxford Scholarship Online, (pp. 405-434).

Burrows, R. M. \& Corragio, M. A. (2011, November 30- December 2). Living walls: integration of water re-use systems. Cities Alive. [Conference presentation]. 9th Annual Green Roof and Wall Conference, Philadelphia, PA, United States.

Çorakçı, R. E. (2016). İç mimarlıkta biyofilik tasarım ilkelerinin belirlenmesi (Publication No. 444471) [Doctoral dissertation, Mimar Sinan Fine Arts University]. 
Day, C. (2007). Environment and children: Passive lessons from the everyday environment. Architectural Press.

Demircioğlu, N. \& Yılmaz, H. (2005). Işık kirliliği, ortaya çıkardığı sorunlar ve çözüm önerileri. Atatürk Üniversitesi Ziraat Fakültesi Dergisi, 36, 117123.

Derr, V. (2001). Children's sense of place in northern new mexico. Journal of environmental psychology, 22(1-2), 125-137.

Derr, V. \& Lance, K. (2012) Biophilic Boulder: Children's Environment That Foster Connection to Nature. Children, Youth and Environments, 22(2), 112-143.

Downton, P., Jones, D., Zeunert, J., \& Roös, P. (2017). Biophilic design applications: Putting theory and patterns into built environment practice. KnE Engineering, 2(2), 59.

Faber, T., Kuo, A. \& Kuo, F. E. (2006). Is contact with nature important for healthy child development? state of the evidence. Cambridge University Press, 124-140.

Fan, M., \& Y. Jin. (2013). Obesity and self-control: Food consumption, physical activity, and weight-loss intention. Applied Economic Perspectives and Policy, 36, 125-45.

Fromm, E. O. (1964). The Heart of Man. Harper \& Row.

Ginsburg, K. R. (2007). The importance of play in promoting healthy child development and maintaining strong parent-child bonds. Pediatrics, 119(1): 182-191.

Hand, K. L., Freeman, C., Seddon, P. J., Recio, M. R., Stein, A., \& Heezik, Y. van. (2017). The importance of urban gardens in supporting children's biophilia. Proceedings of the National Academy of Sciences, 114(2), 274279.

Hare, T. A., C. F. Camerer, \& A. Rangel. (2009). Self-control in decisionmaking involves modulation of the PFC valuation system. Science, 324, 646-48.

Hildebrand, G. (2000). The origins of architectural pleasure. University of California Press.

İslamoğlu, A. H. \& Alnıaçık, Ü. (2014). Sosyal bilimlerde araştırma yöntemleri. Beta Basım Yayım Dağıtım A.Ș.

Joye, Y. (2012). Restorative environments in environmental psychology: an introduction. Jhon Wiley \& Sons.

Kellert, S. R. (1997). Kinship to mastery: biophilia in human evolution and development. Island Press.

Kellert, S., Heerwagen, J.H. \& Mador, M.L. (2008). Biophilic design: the theory, science \& practice of bringing buildings to life. John Wiley \& Sons.

Kellert, S. R. \& Wilson, E. O. (1993). The biophilia hypothesis. Island Press.

Kuo, F.E. \& Sullivan W.C. (2001). Environment and crime in the inner citydoes vegetation reduce crime? Environmental Behaviour, 33, 343-367.

Ostendorf, M. \& Retzlaff, W. \& Thompson, K. (2011, November 30December 2). Storm water runoff from green retaining wall systems; Cities 
alive. [Conference presentation].9th Annual Green Roof and Wall Conference, Philadelphia, PA, United States.

Park, S.H. \& Mattson, R.H. (2008). Effects of Flowering and Foliage Plants in Hospital Rooms on Patients Recovering from Abdominal Surgery. Horttechnology, 18, 563-568

Park, S. J., \& Lee, H. C. (2019). Spatial design of childcare facilities based on biophilic design patterns. Sustainability, 11(10). https://doi.org/10.3390/su11102851

Roös, P.B. (2016). Regenerative-adaptive design for coastal settlements: a pattern language approach to future resilience [Unpublished doctoral dissertation]. Deakin University.

Sayuti, A., Montana-Hoyos, C. A. \& Bonollo, E. (2015). A study of furniture design incorporating living organisms with particular reference to biophilic and emotional design criteria. Academic Journal of Science, 04(01):75-106

Schroll, E., Lambrinos, J. \& Righetti, T. (2011). The role of vegetation in regulating stormwater runoff from green roofs in a winter rainfall climate. Ecol Engineering, 37, 963-969

Sever, İ., A. (2020). Covid-19 Pandemisi sonrası normalleşme sürecinde mobil mekânların mimari tasarım ölçütleri ve bir çözüm önerisi. Mimarlık ve Yaşam Dergisi, 5(2), 477-485, https://doi.org10.26835/my.751807.

Söderlund, J. \& Newman, P. (2015). Biophilic architecture: a review of the rationale and outcomes. Environmental Science, 2(4), 950-969, doi: 10.3934

Thomson, G. \& Newman, P. (2021). Green infrastructure and biophilic urbanism as tools for integrating resource efficient and ecological cities. Urban Planning, 6, 75-88. DOI: 10.17645/up.v6i1.3633

Wells, N. M. \& Evans G.W. (2003). Nearby nature: a buffer of life stress among rural children. Environment and Behavior, 35, 311-330.

White, M., Smith, A., Humphryes, K., Pahl, S., Snelling, D. \& Depledge, M. (2010). The importance of water for preference, affect, and restorativeness ratings of natural and built scenes. J. Environ. Psychol, 30, 482-493

Wilson, E. O. (1984). Biophilia. Harvard University Press, Harvard.

Yamane, T. (2009). Temel örnekleme yöntemleri. Literatür Yayınları.

Zajonc, R. B. (1980). Feeling and thinking: preferences need no inferences. American Psychologist, 35(2), 151-175.

\section{Resume}

Nihan Ünal is a PhD graduate in the Department of Interior Architecture at Mimar Sinan Fine Arts University. She got his bachelor's degree in Interior Architecture and Environmental Design from Bilkent University in 2011 and her MSc degree in Interior Architecture from Cankaya University in 2014. 
Esin Sarıman Özen has been working at Mimar Sinan Fine Arts University, Faculty of Architecture, Department of Interior Architecture since 2008. During this time, she organized and managed various workshops as well as national and international projects. Sarıman Özen conducts research on Adaptive Reuse, Industrial Heritage, Sustainability, Micro Space and Highrise Buildings. 